\title{
Environmental perception in traditional communities: a study in Soure Marine Extractive Reserve, Pará, Brazil
}

\author{
Davison Márcio Silva de Assis \\ Ana Cláudia Caldeira Tavares-Martins \\ Norma Ely Santos Beltrão \\ Priscila Sanjuan de Medeiros Sarmento
}

${ }^{1}$ Federal University of Pará, Belém, PA, Brazil

${ }^{\text {Il }}$ State University of Pará, Belém, PA, Brazil

III State University of Pará, Belém, PA, Brazil

IV State University of Pará, Belém, PA, Brazil

\begin{abstract}
The Soure Marine Extractive Reserve, located in the Marajó Archipelago, was created to protect its biodiversity and guarantee the sustainability of its ecosystems. Despite of it, local environmental problems have increased. In this sense, this study aimed to quantify the level of environmental perception, in four categories, of communities settled within this conservation unit, based on a score classification (from 1 to 10). To this end, questionnaires were created with the structure of a 5-point Likert scale and applied to the participants. The results were quantified and revealed high scores (above 9) in the four categories analyzed, indicating a high level of perception. Perception was associated with age, schooling and number of people in the household. As a high level of perception was found, it is recommended that the awareness-raising actions carried out by the managing body of the reserve be maintained in order to preserve this knowledge.
\end{abstract}

Keywords: Amazon; Traditional Knowledge; Likert scale.

São Paulo. Vol. 23, 2020

Original Article

DOI: http://dx.doi.org/10.1590/1809-4422asoc20190148r1vu2020L6AO 


\section{Introduction}

Research focusing on cognitive and affective aspects has been gaining momentum due to its contribution to the understanding of the man-nature relationship (BARROS; PINHEIRO, 2013). Research developed in this field has revealed that individuals who have a close relationship with nature demonstrate greater awareness of its importance and conservation (RODRIGUES, 2009). In this context, the study of environmental perceptions can provide a better clarification of these relationships, as it aims to understand the human experience in environments, alluding not only to their physical aspects, but also to the way people understand and interpret their surroundings (BARROS; PINHEIRO, 2017).

According to neuroscience, perception is a mental process characterized as the individual's interaction with the environment, occurring through perceptual stimuli captured by the five senses combined with the subject's active contributions, ranging from motivation to conduct itself (RIBAS et al., 2010). Within the socio-environmental perspective, perception is defined as an individual process of perceiving, understanding and relating to the environment, taking into account ideological influences and socioeconomic factors such as gender, age, social class, income and education (TRENOUTH et al., 2012).

In a given socio-cultural context, individuals build their perceptions not only based on the stimuli received from the environment, but also on their historical context and socially determined patterns (GONÇALVES; GOMES, 2014). In this sense, each individual will have a perception based on his particular vision and interpretation of the environment in which he is inserted, considering his previous experiences, expectations and anxieties (HOEFFEL et al., 2008; GONÇALVES; HOEFFEL, 2012).

Regarding the man-nature relationship within the context of the Amazon, communities that are characterized by their traditional way of life and by the environmental sustainability of their socioeconomic practices reveal knowledge based on perceptions of an ecologically correct world (SILVA; SIMONIAN, 2015). In this sense, it is essential to know such perceptions, since they can act as a diagnostic tool and can guide the planning of strategies of use of spaces and natural resources (OLIVEIRA et al., 2018). It is known, therefore, that the human groups residing in Extractive Reserves are models of the relationship between society and nature (SILVA; SIMONIAN, 2015) which can contribute with information on the use, management and conservation of biodiversity.

The Soure Marine Extractive Reserve (Soure RESEX-Mar) was created with the advent of environmental problems caused by migrants from other regions who practiced inadequate exploitation of natural resources, such as fishing and crab collection during the closed season (LOBATO et al., 2014).

The Soure RESEX-Mar was created in 2001 (BRASIL, 2001), but the way of life established in the area is a product of the creation and transmission of knowledge that goes back over a century of interaction of the populations settled there with nature (CARDOSO, 2014). Such knowledge may have consolidated important perceptions and serve as a basis for management as well as guidance of the development of policies and programs aimed at conservation. 
Given the relevance of studies on the perception and knowledge of the environment of traditional populations in extractive reserves, the following question is raised: What is the level of environmental perception of the communities settled in Soure RESEX-Mar? Is the level of perception associated to socioeconomic variables? Do different communities have the same level of perception? Does environmental perception vary between genders?

Based on these guiding questions, the objective of this study was to quantify and understand the level of environmental perception of traditional communities settled in Soure RESEX-Mar, and verify whether these perceptions are influenced by socioeconomic and demographic variables.

\section{Methodology}

2.1 Characterization of the study area

The Soure RESEX-Mar is a federal conservation unit with a territorial extension of 27,463.58 hectares, inserted in the Marajó Archipelago. Three communities are settled within the limits of Soure RESEX-Mar (figure 1): Vila de Pesqueiro, Comunidade do CajuÚna and Povoado do Céu located $7 \mathrm{~km}, 18 \mathrm{~km}$ and $23 \mathrm{~km}$ from the urban center of the city of Soure, respectively. The two latter are very close to each other (OLIVEIRA, 2012).

Figure 1 - Location of Soure Marine Extractive Reserve, Pará, Brazil.

MAPA DE LOCALIZAÇÃO DA RESEX-MAR DE SOURE

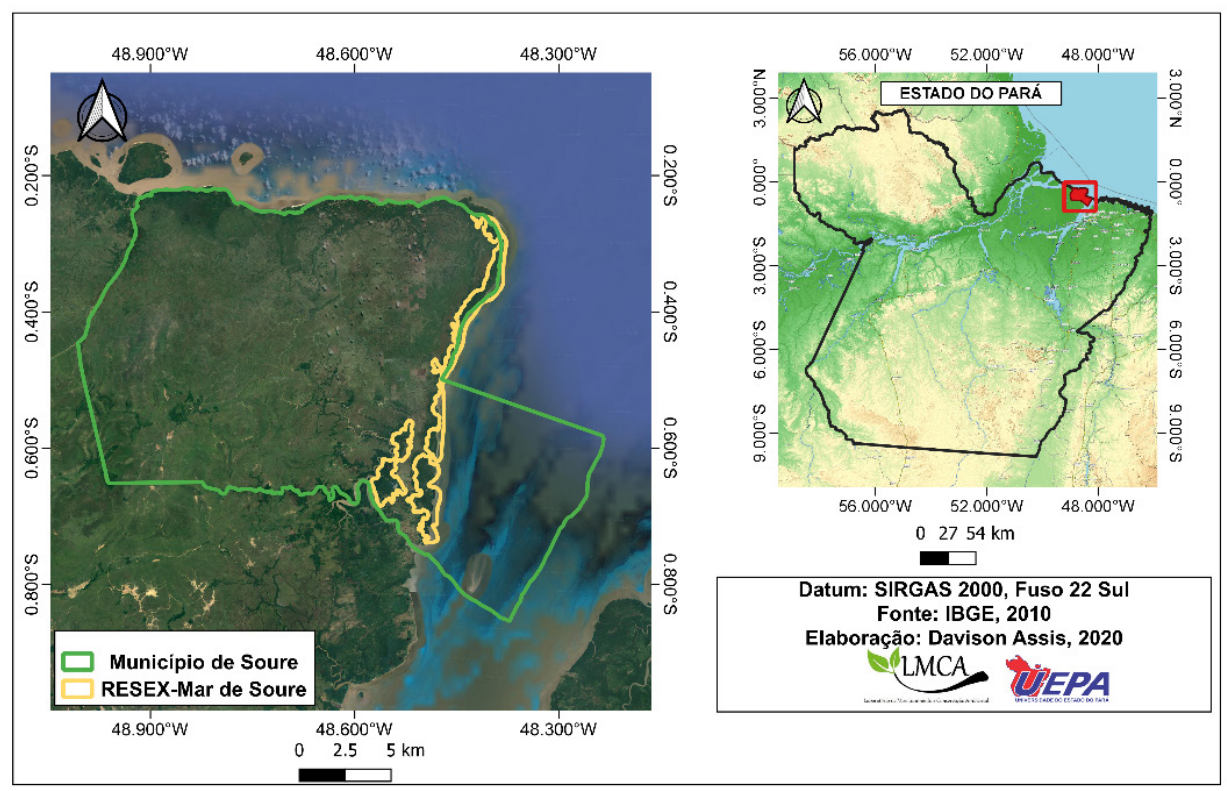

Source: authors, 2020 
The target audience of this research is inserted in natural environments whose vegetation is composed of sandbank areas represented by shrubs and herbs of the genera Anacardium sp., Byrsonima sp., Annona sp. and Acacia sp., which occur on sand plains and dunes near the coast (COHEN et al., 2008). Mangrove forests are also observed in these environments, with the species Rhizophora racemosa G. Mey., Avicennia germinans (L.) L. and Pachira aquatica Aubl., as well as dry and flooded fields with Poaceae, Cyperaceae and Fabaceae representatives, and 'tesos' - anthropogenic embankments created during the occupation of the island by pre-Columbian populations - with Arecaceae, Rubiaceae and Bignoniaceae representatives (LISBOA, 2012).

\subsection{Socioeconomic Characterization}

With regard to the economy, the three communities share the same sources of income, mainly involving fishing resources (fish, shrimp and crab), vegetable extraction, agriculture, social benefits such as Seguro Defeso (benefit paid to artisanal fishermen), Bolsa Verde (environmental conservation support program) and Bolsa Família (direct income transfer program targeted at poor families), pensions and salaries of civil servants, and in the case of Vila do Pesqueiro, tourism activities (OLIVEIRA, 2012; PINHEIRO et al., 2014).

Most people live in stilt houses built with funds from federal financing projects in partnership with the National Institute of Colonization and Agrarian Reform (INCRA) (OLIVEIRA, 2012). These houses receive electricity and the water supply is still precarious; in the case of Vila do Pesqueiro, there is piped water supply, but in Comunidade do Caju-Úna and Povoado do Céu, water is obtained from community wells and/or water trucks (LOBATO et al., 2014).

As for medical assistance, each community has a health post and health agents and nurses monitor the status and treatments of common illnesses such as viral infections, diarrhea, headaches, stomach problems and injuries, and the most serious cases are referred to the municipality of Soure or Belém (ROCHA; TAVARES-MARTINS; LUCAS, 2017).

Each community has a community center that usually hosts religious and cultural events, training courses and association meetings. Public schools in the communities are linked to the municipality of Soure and provide only elementary school I; students of more advanced grades use the school bus to attend classes at the municipality's headquarters.

Residents of each of the three communities are organized into associations related to the professions and causes of interest of the populations, namely, the Association of Residents of Povoado do Céu (AMPOC), the Association of Residents of Comunidade do Caju-Úna (AMCOC), and the Association of Residents of Vila de Pesqueiro. These associations are important because the health post, headquarters of the community center, and public school of each community were obtained through them (CARDOSO, 2014).

In general, the three communities are part of the Association of Soure Marine Extractive Reserve (ASSUREMAS), whose purpose is to manage social organizations, 
representing all users and managing the Federal Programs for the extractivists (OLIVEIRA, 2012).

\subsection{Data collection}

The research project was submitted to the platform of the National System of Management of Genetic Heritage and Associated Traditional Knowledge (SISGEN), and received the registration number A4AEA5D.

Based on the survey conducted by Rocha; Tavares-Martins; Lucas (2017), who estimated a population of approximately 249 families in Soure RESEX-Mar, the sample was calculated with a confidence level of $94 \%$, according to the following equation:

$$
n_{o}=\frac{1}{E_{o}^{2}} \text {. }
$$

Where $E_{o}^{2}$ corresponds to the sampling error, which was $6 \%$ in the present study. The corrected sample size $\mathrm{n}$ was obtained using the equation:

$$
n=\frac{N n_{o}}{N+n_{o}}
$$

Where $n$ corresponds to the sample size, $N$ to the population size and $n_{0}$ to the first approximation of the sample size. In this sense, for the population $\mathrm{N}=249$ families, the $(n)=131$ was obtained, which corresponds to the number of interviews that were carried out.

\subsubsection{Preparation of forms}

The forms were composed of two sections: i. socioeconomic characterization, including: a. gender, b. age, c. time of residence in the community, d. annual income, e. number of people in the household, and f. schooling; and ii. environmental perception. For the analysis of environmental perception, structured statements were presented on a 5-point Likert scale (BERMUDES et al., 2016) and the respondents indicated their degree of agreement with the situation presented.

The significance of the scale focused on the participants' perception of the following elements: a. Perception about solid waste; b. Importance of the mangrove and its resources; c. Perception about forests and their resources; and d. Perception about environmental awareness programs at the Soure RESEX-Mar. The statements in the scale were answered choosing one of the following alternatives: a. Never or I strongly disagree, b. Rarely or I partially disagree, c. Indifferent, d. Frequently or I partially Agree e. Very frequently or I totally agree.

As recommended by Günwsther (2003) and Chaer et al. (2012), before the in- 
terview for data collection, the forms were tested with two active community members to verify the quality and clarity of the questions and their adequacy to the objective of the study.

\subsubsection{Interviews}

The proposal of this work was submitted for appraisal and approval by the studied communities. To this end, a Prior Consent Term (PCT) was provided and signed by the leaders of the three communities.

The data collection method used in this work is characterized as survey data collection, which allows the use of a form as a script for interviews (GÜNWSTHER, 2003). Structured forms were applied through interviews from February to March 2018, comprising two excursions of fifteen days each. In the first, 58 residents from Vila de Pesqueiro were interviewed, and in the second 73 residents - 40 from Comunidade do Caju-Úna and 33 from Povoado do Céu -, totaling 131 respondents.

The criterion adopted for the choice of informants was that they should be over 16 years old and be permanent residents of one of the communities, as according to Lobato et al. (2014) many extractivists come from areas out of the reserve, but use and benefit from its resources. There are also people who have a house in the studied communities, but live in the municipal pole of Soure or in another municipality, usually Icoaraci and Belém.

\subsection{Analysis of perceptions}

The appraisals were made based on Content Analysis, which is a modality of interpretation that seeks to extract expressed or latent meanings from a message. Such meanings are categorized into lexical or thematic units composed of indicators that allow the enumeration of the units, and from there, the establishment of generalizing inferences (CHIZZOTTI, 2014).

In Content Analysis, the researcher seeks to penetrate into the ideas, mentalities, values and intentions of the producer of the communication to understand his message. Themes that relate to the sociocultural context of the producer of the message are analyzed, namely, his intentions, pressures, circumstances and the ideology that conditioned the production of the message in an effort to articulate the objective and quantitative rigor with comprehensive and qualitative richness (CHIZZOTTI , 2014).

The following categories were adopted in this study: a. Perception about solid waste (pollution, attraction of disease vectors, recycling, reuse); b. Perception about the importance of the mangrove and its resources (extraction of wood, crabs, closed season, disposal of solid waste in the mangrove); c. Perception about forests and their resources (deforestation, burning, predatory hunting, disposal of solid waste in the forest, bioprospecting, sustainability, conservation); and $\mathrm{d}$. Perception about environmental awareness programs at the Soure RESEX-Mar (creation and participation of environmental education programs and projects and actors responsible for conservation). These categories were analyzed qualitatively and quantitatively in relation to socioeconomic 
variables (age, time of residence in the community, number of people in the household, annual income, and schooling).

To complement the qualitative analysis, a field journal was adopted in which the events during the working day were recorded, as well as the understandings about the people and the relationships with those with whom contact was maintained (ALBU. QUERQUE et al., 2010).

\subsection{Data processing and application of statistical tests}

To quantify the environmental perception of residents, a classification based on Brandalise et al. (2009) with adaptations in Audino (2017) was made, as presented in table 1 .

Table 1 - Classification and values of the levels of environmental perception

Classification of perception

Has no perception

Has small signs of perception

Has potential signs of perception

Has perception

Has high perception

\section{Score}

0 to 2.0

2.1 to 4.0

4.1 to 6.0

6.1 to 8.0

8.1 to 10

Source: Brandalise et al. (2009) with adaptations in Audino (2017)

The the Spearman correlation coefficient $\left(r_{s}\right)(Z A R, 2009)$ was applied to test the correlation between levels of perception and age, time of residence in the community, number of people in the household, annual income and schooling. Differences in the levels of perception between communities and between men and women were tested using analysis of variance (ANOVA) and t test, respectively.

When the assumptions of the analysis were not met (independent samples, homogeneity of variances, residues with normal distribution), equivalent non-parametric tests (Kruskal wallis and Mann Whitney) were used (ZAR, 2009). All statistical analyses were performed using the PAST software version 3.18 (HAMMER et al., 2001).

\section{Results and discussion}

\subsection{Perception about solid waste}

The results showed that $98 \%$ of the informants had a high perception (9.7) about the influence of solid waste in the environment. These findings reveal that issues such as pollution, low soil fertility and attraction of disease vectors caused by inadequate disposal 
are highly perceived by the respondents.

The statements of this section were prepared also considering a socioeconomic context, alluding to recycling as a source of income and the use of organic waste for fertilization. High levels of perception among interviewees lead us to infer that the materials that are generally released to the environment are seen by them as raw material for making handicrafts and as organic fertilizers, which if reused and correctly used can benefit users.

In their report of the environmental threats present in Soure RESEX-Mar, Lobato et al. (2014) mention the presence of solid waste debris on beaches as one of the most frequent. However, in the present study, some residents pointed out that many of the residues found on beaches are extraneous material carried down from other places by tides. These reports are stressed by the speech of A. G., 46 years old, resident of Povoado do Céu:

"The garbage on the seashore is brought by the tide from other places, we see packs in other languages".

Another part of the solid waste found in these places is of natural origin, such as coconut shells, dry branches, leaves and seeds, which, according to L. S., 38 years old, resident of Vila de Pesqueiro, are important to contain the advance of the tides over their territories. It was observed that the high perception of these populations originates from their traditional knowledge, because these reports demonstrate knowledge built on the basis of everyday experiences. Such knowledge is transmitted orally from generations to generations and denotes a close relationship between man and nature (ABREU; DOMIT; ZAPPES, 2017).

The level of perception of this category was significantly different between the three communities $(\mathrm{H}=0.16 \mathrm{p}=0.002)$; residents of Vila de Pesqueiro showed a smaller perception than those of Comunidade do Caju-Úna and Povoado do Céu (table 2). It is believed that the lack of solid waste collection in the last two communities stimulated residents to seek alternatives for the final destination of this waste in order to avoid the consequences of its exposure in the environment. In view of the risk of environmental pollution and damage to human health (LAURENT et al., 2014), and considering that the perception is the product of the individuals' sensitivity to the reality experienced (NOVAIS et al., 2015), it is believed that the susceptibility of these communities to threats caused by inadequate disposal of solid waste has generated greater awareness among them. 
Table 2 - Analysis of variance on the level of perception of solid waste among residents of the three communities at the Soure RESEX-Mar

\begin{tabular}{lccc}
\cline { 2 - 3 } & Vila de Pesqueiro & $\begin{array}{c}\text { Comunidade do } \\
\text { Caju-Úna }\end{array}$ & Povoado do Céu \\
\hline Vila de Pesqueiro & $0.005894^{*}$ & $0.005894^{*}$ & $0.005526^{*}$ \\
\hline $\begin{array}{l}\text { Comunidade do Ca- } \\
\text { ju-Úna }\end{array}$ & $0.005526^{*}$ & 0.4668 & 0.4668 \\
\hline Povoado do Céu & & \\
\hline
\end{tabular}

Source: Authors, 2018

Note: *Statistically significant difference

However, regarding the actions taken by residents of Comunidade do Caju-Úna and Povoado do Céu to minimize the impacts of waste left exposed in the environment, the most frequent are burning and burial (LOBATO et al., 2014). It is noteworthy that, although this attitude reflects the concern of the community with the issue, the actions adopted end up creating other problems because burning can release toxic particles into the atmosphere, altering air quality and affecting human health (ZHENG et al., 2018). Another potential risk is soil contamination by burial of waste, also with the risk of contamination and alteration of soil quality, and negative effects on human health (SANTUCCI et al., 2018). The absence of adequate sites for disposal of solid waste and the lack of collection services give reasons for the population to dispose it improperly (FERREIRA et al., 2016).

In view of this situation, it is emphasized that the communities need better assistance from competent public agencies, which have to fulfill their role in protecting natural environments and the populations established there. It is also recommended that the waste generated by the population be collected on a daily basis, for public health and sanitary reasons (LINO; ISMAIL, 2018).

In a complementary manner, actions can be taken to raise awareness among the local populations about the impacts of burning and burying solid waste. This could be done through projects to inform the harmfulness of these practices to the environment and human health. In the same way, actions that reinforce the importance and role of recycling, reuse, proper disposal of waste and attitudes to reduce its production can also be adopted, reinforcing that attitudes like these can be much more beneficial to the environment than the current methods practiced by residents (NASCIMENTO et al., 2017). In this sense, it is essential to plan actions of this nature, sensitizing populations to adopt sustainable practices and recognize the limits of human intervention in the environment (PAULA et al., 2014).

Finally, it was observed that the populations had a high perception of the influences of solid waste in their daily lives, but the little government assistance and lack of 
a waste management program prevent them from using effective strategies to give it a suitable destination. The t test revealed no statistical difference in the level of perception of solid waste between genders $(U=2118 \mathrm{p}=0.91)$, nor correlation between the level of perception and socioeconomic variables (table 3 ).

Thus, variables such as gender, age group, time of residence in the community, annual income, number of people in the household, and time of schooling did not affect the respondents' level of perception about issues related to solid waste. This result reinforces the traditional character of these populations, in which perceptions about the environment where they live are structured in a unique and somewhat homogeneous way, without producing variations in the way they see the environment.

Table 3 - Correlation of socioeconomic variables with the level of perception in the three categories analyzed

\begin{tabular}{|c|c|c|c|c|c|c|}
\hline & \multicolumn{2}{|c|}{ Solid waste } & \multicolumn{2}{|c|}{$\begin{array}{l}\text { Mangrove and its } \\
\text { resources }\end{array}$} & \multicolumn{2}{|c|}{$\begin{array}{l}\text { Forest and its } \\
\text { resources }\end{array}$} \\
\hline & rs value & $\mathrm{p}$ value & $\begin{array}{l}\text { rs va- } \\
\text { lue }\end{array}$ & $\mathrm{p}$ value & rs value & $\mathrm{p}$ value \\
\hline Age & -0.08 & 0.12 & -0.20 & $0.01 *$ & -0.02 & 0.75 \\
\hline Time of residence & -0.08 & 0.36 & -0.11 & 0.18 & -0.09 & 0.30 \\
\hline Annual income & -0.07 & 0.39 & -0.14 & 0.08 & -0.04 & 0.60 \\
\hline $\begin{array}{l}\text { Number of people } \\
\text { in the household }\end{array}$ & -0.03 & 0.65 & 0.15 & 0.06 & 0.18 & $0.03 *$ \\
\hline Schooling & 0.12 & 0.14 & 0.18 & $0.03 *$ & 0.11 & 0.18 \\
\hline
\end{tabular}

Source: Authors, 2018

Note: *Statistically significant relationship

\subsection{Perception about the mangrove and its resources}

The results revealed that $98 \%$ of the informants had a high perception (9.7) of the mangrove and its resources, demonstrating that the traditional communities, which live close to the mangroves and depend on their resources, have a wide knowledge of its importance and benefits (MUNJI et al., 2014; CORMIER-SALEM et al., 2017).

At Soure RESEX-Mar, the main benefits derived from the mangrove are linked to crab extraction for own consumption and commercialization (LOBATO et al., 2014). Regarding plant resources, the mangroves provide plants employed in five categories of use, namely, construction, river markers, medicine, repellent, and coal production (RO- 


\section{CHA; TAVARES-MARTINS; LUCAS, 2017).}

For some residents, mangroves are extremely important not only for the provision of vegetable raw material and proteins (crab), but mainly for the persistence of some fish, shrimp and crab species, considering that these products are the most appreciated by the residents. According to reports of R. L., 43 years old, resident of Vila de Pesqueiro:

"The mangrove is a nursery of the RESEX, as it is where the spawning of some species of fish such as catfish, and shrimp and crabs occurs".

Traditional knowledge is again observed as the foundation of the perceptions raised here, contributing to the high score found in this category, as the interviewee demonstrates a clear perception of the origin of the resources from which they benefit.

The analysis of variance revealed that there was no differences in the perception of the three communities $(\mathrm{H}=1.93 \mathrm{p}=0.24)$. Although the level of perception between communities did not vary, differences were seen between genders $(U=1719 p=0.01)$, indicating that women had a greater perception.

In their study of useful plants in the three communities of Soure RESEX-Mar, Rocha; Tavares-Martins; and Lucas (2017) observed that $80 \%$ of the informants were of the female sex, and demonstrated a deep knowledge about the ways of using resources from different environments, including mangroves. As women play a broader role in the family, being responsible for food, health, in addition to helping supplement the household income through the production of handicrafts, they end up developing a closer bond with the resources coming from natural environments, precisely because of such practices. This explains the mentions made of medicinal plants, food, repellent agents, charcoal and biojewelry in the cited study, which contributed to the greater perception among women.

The Spearman correlation test (table 3) showed that age and schooling were correlated with the level of perception of the mangrove and its resources; the higher the individual's age and education, the greater his level of perception. These results are in line with other studies that indicated the positive influence of socio-demographic factors such as age and education on the perception of community members about the importance and conservation of the mangrove (ROY, 2014; ROY, 2016; BADOLA et al., 2012).

In the case of the present study, it is believed that the subjects' experiences over the years at Soure RESEX-Mar have contributed to a better understanding of the dynamics and functioning of this ecosystem. Such experience is translated into traditional knowledge, which may have contributed for older respondents to demonstrate a greater perception. Similarly, it is also believed that higher levels of schooling lead to a better understanding of these processes, and education seems to have generated a greater awareness of issues related to this ecosystem in the informants. According to Silva et al. (2015) and Magalhães et al. (2010), older and more educated individuals tend to have a greater perception of ecological issues, which consequently contributes to a higher level of environmental perception. 


\subsection{Perception of forests and their resources}

As to the perception of all forest environments at Soure RESEX-Mar, the score found was 9.5, which is classified as high. It is conjectured that this result is linked to the high degree of dependence of the residents on forest resources, considering that many of them are directly obtained from the forest.

The results also indicate that issues such as deforestation, fires, predatory hunting, solid waste disposal, bioprospecting, sustainability and conservation, which formed the core for the statements in this category, were perceived by respondents as of major importance to the sustainability of the ecosystem. It is believed that these perceptions are based on traditional knowledge, since the populations living in extractive reserves support their practices of use of natural resources on sets of knowledge from an ecologically correct world (SILVA; SIMONIAN, 2015).

The results show that there was no significant difference between the three communities regarding the level of perception of forests and their resources ( $t$ test: $F=1.30 p=$ $0.32)$ nor between men and women $(U=1851 \mathrm{p}=0.18)$, indicating that the knowledge among informants from different communities and genders on the topic is homogeneous.

Literature data indicates that it is common to see differences between genders when it comes to the level of perception of forests and benefits derived from them. For Jokinen et al. (2018) and Allendorf and Yang (2017), as women have less knowledge and understanding of forest management and a smaller participation in decision-making within communities, they generally have a lower perception. Thus, the present study brings an atypical case, because the perception was the same among men and women. It is believed that this occurs thanks to the relationship developed over the years by women with the forest and its resources.

The participation of women is not restricted to domestic chores, as resources (fruits) such as coconut, muruci, cashew, ajiru, miri and tucumã are extracted and traded by them as an alternative to supplement the family income during the off-season period of fish production. Another activity that illustrates this relationship is the manufacture of handicrafts and bio-jewels, especially in Vila de Pesqueiro, where women collect seeds on the beach and in the forest to use them as raw material for handicraft production.

Other forms of direct and indirect use of forest resources by women are the collection of tucumã seed for the extraction of "óleo-de-bicho" (oil obtained from larvae) (ROCHA; TAVARES-MARTINS; LUCAS, 2014) and collection of andiroba nuts carried to the seashore by tides, which are used for oil extraction (ROCHA; TAVARESMARTINS; LUCAS, 2017). Again, it is observed that the high perception of women is explained by the intense interaction developed with nature through activities of extraction and use of resources from natural environments. This integration culminates in the frequent participation of women in the meetings of community associations and in the Deliberative Council of the reserve, to discuss territorial, festive, religious and especially socio-environmental matters.

It was observed that the only socioeconomic variable that was associated with the perception of forests and their resources was the number of people in the house- 
hold (Spearman correlation coefficient: $\mathrm{p}=0.03$ ) (table 3); the larger the household, the greater the individual's perception. It is believed that this result is indicative of the dependence of users of Soure RESEX-Mar on forest products, in which greater numbers of people in a residence imply a greater need to use and exploit resources. Allied to the concern with the subsistence of a family nucleus that depends on such resources, a high environmental conscience was seen among these residents, who agreed on that hunting, frequent extraction of products, deforestation and pollution cause harms, with losses for the forest and for themselves (SOE; YEO-CHANG, 2019).

\subsection{Perception about environmental awareness programs at the Soure RESEX-Mar}

In this category of analysis, the respondents showed a high perception (9.8), agreeing on the importance of environmental education programs and projects and on that conservation is the responsibility of all social actors involved in Soure RESEX-Mar.

On the other hand, the high score is attributed to awareness campaigns of the local population, mostly carried out, in past and present moments, through projects that emphasize the importance of preserving nature. Within this context, to highlight the importance of mangrove preservation, the Chico Mendes Institute for Biodiversity Conservation (ICMBio) created the project "Manguezal: conhecendo e protegendo" (Mangroves: knowing and protecting), aimed at developing educational actions in favor the conservation of these ecosystems, by raising awareness and providing information to children and adolescents of families of users of Soure RESEX-Mar (REPOLHO et al., 2018).

In a similar line, in order to inform the population about the consequences of inadequate waste disposal in coastal ecosystems, ICMBio created the project "Praias de Soure: nosso paraíso marajoara" (Soure beaches: our paradise in Marajó) in partnership with the Federal University of Pará (UFPA) (Campus Soure) and the State University of Pará (UEPA) (Campus XIX). In this project, actions included the distribution of garbage bags and informative material for mobilization and awareness among the local population and vacationers who visited the beaches about the importance of preserving this ecosystem (LOBATO et al., 2014).

In addition to the abovementioned projects, the following projects are also worth of mention: "Jovens Protagonistas" (Young Protagonists), developed to train future community leaders to work on environmental causes of interest to the communities; the "Canteiro communitário" (Community seedbed) project, the result of a partnership between UEPA and ICMBio aimed at the creation of a garden with medicinal species, contributing to the strengthening and preservation of culture and traditional knowledge.

Given these considerations, it appears that the projects developed by ICMBio represent an important instrument used to raise awareness among the local populations, which may have contributed to their high levels of perception. In this sense, it is also worth mentioning that the projects "Mangroves: knowing and protecting" and "Soure beaches: our paradise in Marajó" may have contributed to the high perception of informants both in the category "Perception about environmental awareness programs at the 
reserve" and also in "Perception about solid waste" and "Perception about the importance of the mangrove and its resources", because these projects focused on sensitizing the local population and visitors on the potential threats to mangroves and beaches, respectively.

The way in which residents perceive the importance of mangroves, forests, solid waste and environmental awareness programs can be decisive for ensuring the sustainability of this conservation unit, for sustainability depends on how individuals perceive and related with the environment (ARETANO et al., 2017).

The analysis of variance revealed the absence of statistically significant differences in the level of perception of environmental awareness programs between the three communities $(\mathrm{H}=2.21 \mathrm{p}=0.14)$, and the $\mathrm{t}$ test showed absence of differences between men and women $(U=1955 \mathrm{p}=0.25)$, and there was no correlation with socioeconomic variables. These results, as well as those of the former categories, mangroves and forests and their resources, reinforce that the knowledge of the communities about environmental issues is homogeneous and translated into a high level of perception that does not vary between communities and genders.

Considering the importance of resources for the informants and given their relationship of dependence in several categories, it is inferred that preserving natural environments goes hand in hand with their interests, preventing that the benefits derived from these environment are not suppressed in any way, since negative impacts on ecosystems can compromise the availability of resources and consequently their quality of life.

\section{Conclusion}

In view of the above considerations, it is evident that residents of the communities have developed a high level of perception based on their traditional knowledge, associated with awareness-raising projects and the education work carried out by ICMBio environmental analysts in the light of Law number 9,985/2000, which provides the criteria for the management of conservation units, prohibiting the unsustainable exploitation of natural resources or any other form of human intervention that may compromise the sustainability of ecosystems in extractive reserves.

Although the level of perception of residents of Soure RESEX-Mar is high, raising awareness among community members about environmental issues is still a priority action. To this end, it is recommended that the strategies already adopted by the managing body of the reserve, such as the development of projects and environmental inspection actions, be maintained to preserve these perceptions. It is also necessary that the culture and traditional knowledge of the communities be preserved and passed on to younger generations, so that the foundations of these environmental perceptions may be preserved.

\section{References}

ABREU, S. J.; DOMIT, C.; ZAPPES, A. C. Is there dialogue between researchers and traditional 
community members? The importance of integration between traditional knowledge and scientific knowledge to coastal management. Ocean and Coastal Management, v. 141, p. 10-19, 2017.

ALBUQUERQUE, U. P.; LUCENA, R. F. P.; NETO, E. M. F. L. Seleção dos Participantes da pesquisa. In: ALBUQUERQUE, U. P. de, LUCENA, R. F. P. de; CUNHA, L. V. F. C da (Orgs.). Métodos e Técnicas na Pesquisa Etnobiológica e Etnoecológica. Recife, PE: NUPPEA, 2010. (Coleção Estudos e Avanços).

ALLENDORF, T. D.; YANG, J. M. The role of gender in local residents' relationships with Gaoligongshan Nature Reserve, Yunnan, China. Environment, Development and Sustainability, v. 19, p. 185-198, 2017.

AUDINO, V. Elaboração de um instrumento sobre a percepção ambiental da população urbana para a sustentabilidade de cidades. Dissertação apresentada ao Programa de Pós-Graduação em Sustentabilidade Socioeconômica e Ambiental, Universidade Federal de Ouro Preto. 2017.

ARETANO, R.; PARLAGRECO, L.; SEMERARO, T.; ZURLINI, G.; PETROSILLO, I. Coastal dynamics vs beach users attitudes and perceptions to enhance environmental conservation and management effectiveness. Marine Pollution Bulletin, v. 123, n. 1, p. 142-155, 2017.

BRANDALISE, L. T.; BERTOLINI, G. R. F.; ROJO, C. A.; LEZANA, Á. G. R.; POSSAMAI, O. A percepção e o comportamento ambiental dos universitários em relação ao grau de educação ambiental. Gest. Prod., São Carlos, v. 16, n. 2, p. 273-285, 2009.

BADOLA, R.; BARTHWAL, S.; HUSSAIN, S. A. Attitudes of local communities towards conservation of mangrove forests: a case study from the east coast of India. Estuarine, Coastal and Shelf Science, v. 96, p. 188-196, 2012.

BARROS, H. C. L.; PINHEIRO, J. Q. Dimensões psicológicas do aquecimento global conforme a visão de adolescentes brasileiros. Estudos de Psicologia, v. 18, n. 2, p. 173-182, 2013.

BARROS, H. C.; PINHEIRO, J. Q. Mudanças climáticas globais e o cuidado ambiental na percepção de adolescentes: uma aproximação possível. Desenvolvimento e Meio Ambiente, v. 40, p. 189-206, 2017.

BERMUDES, W. L.; SANTANA, B. T.; BRAGA, J. H. O.; SOUZA, P. H. Tipos de escalas utilizadas em pesquisas e suas aplicações. Revista Vértices, v. 18, n. 2, p. 7-20, 2016.

BRASIL. Decreto sem número de 22 de novembro de 2001. Cria a Reserva Extrativista Marinha de Soure, no Município de Soure, Estado do Pará, e dá outras providências.

CARDOSO, M. S. C. Pescadores da Reserva Extrativista Marinha de Soure: práticas sociais no território. Belém: PPGSS/ICSA/UFPA, 2014. Dissertação de mestrado. 162 p.

CHAER, G.; DINIZ, R. R. P.; RIBEIRO, E. A. A técnica do questionário na pesquisa educacional. Revista Evidência, v. 7, n. 7, p. 251-266, 2012.

CHIZZOTTI, A. Pesquisa qualitativa em ciências humanas e sociais. Petrópolis, RJ: Vozes, 
2014

COHEN, M. C. L.; LARA, R. J.; SMITH, C. B.; ANGÉLICA, R. S.; DIAS, B. S.; PEQUENO, T. Wetland dynamics of Marajó Island, northern Brazil, during the last 1000 years. Catena, v. 76, p. 70-77, 2008.

CORMIER-SALEM, M. C.; VAN TRAI, N.; BURGOS, A.; DURAND, J. D.; BETARREL, Y.; KLEIN, J.; DUC HUY, H.; PANFILI, J. The mangrove's contribution to people: Interdisciplinary pilot study of the Can Gio Mangrove Biosphere Reserve in Viet Nam. Comptes Rendus - Geoscience, v. 349, p. 341-350, 2017.

FERREIRA, C. F. C.; CAMPOS, G. A.; CASTRO, J. S.; SILVA, M. H. L.; CARDOSO, R. L.; ANDRADE, T S O M; NETA, R N F C. Percepção ambiental sobre usos dos recursos aquáticos e sua relação com os resíduos sólidos no Rio Anil: estudo de caso para subsidiar ações educativas em São Luís - MA. Pesquisa em Foco, v. 21, n. 2, p. 25-40, 2016.

GÜNWSTHER, H. Como Elaborar um Questionário (Série: Planejamento de Pesquisa nas Ciências Sociais, № 01). Brasília-DF: UnB, Laboratório de Psicologia Ambiental, 2003.

GONÇALVES, B. V.; GOMES, L. J. Percepção ambiental de produtores rurais na recuperação florestal da sub-bacia hidrográfica do rio Poxim - Sergipe. Desenvolvimento e Meio Ambiente, v. 29, p. 127-138, 2014.

GONÇALVES, N. M.; HOEFFEL, J. L. M. Percepção ambiental sobre unidades de conservação: os conflitos em torno do Parque Estadual de Itapetinga - SP. Revista Vitas - Visões transdisciplinares sobre ambiente e sociedade, v. 3, n. 3, p. 1-15, 2012.

HAMMER, O. et al. PAST: Paleontological Statistic software package for education and data analysis. 2001.

HOEFFEL, J. L.; FADINI, A. A. B.; MACHADO, M. K.; REIS, J. C. Trajetórias do Jaguary - unidades de conservação, percepção ambiental e turismo: um estudo na APA do Sistema Cantareira, São Paulo. Ambiente \& Sociedade, v. 11, n. 1, p. 131-148, 2008.

JOKINEN, M; HUJALA, T; PALONIEMI, R; VAINIO, A. Private landowners and protected species: What sort of noncompliance should we be worried about? Global Ecology and Conservation, v. 15, p. e00407, 2018.

LAURENT, A.; BAKAS, I.; CLAVREUL, J.; BERNSTAD, A.; NIERO, M.; GENTIL, E.; HAUSCHILD, M. Z.; CHRISTENSEN, T. H. Review of LCA studies of solid waste management systems - Part I: Lessons learned and perspectives. Waste Management, v. 34, n. 3, p. 573-588, 2014.

LINO, F. A. M.; ISMAIL, K. A. R. Evaluation of the treatment of municipal solid waste as renewable energy resource in Campinas, Brazil. Sustainable Energy Technologies and Assessments, v. 29, n. June, p. 19-25, 2018.

LISBOA, P. L. B. A terra dos Aruã: uma história ecológica do arquipélago do Marajó. Belém: Museu Paraense Emílio Goeldi, 2012. 482 p. 
LOBATO, G. J. M.; TAVARES-MARTINS, A. C. C.; LUCAS, F. C. A.; MORALES, G. P.; ROCHA, T. T. Reserva Extrativista Marinha de Soure, Pará, Brasil: modo de vida das comunidades e ameaças ambientais. Bioata Amazônia, v. 4, n. 4, p. 66-74, 2014.

MAGALHÃES, H.; BONONI, V. L. R. MERCANTE, M. A. Participação da sociedade civil na gestão de unidades de conservação e seus efeitos na melhoria da qualidade ambiental da região Sudeste do Estado do Mato Grosso do Sul. Acta Scientiarum. Human and Social Sciences, v. 32, n. 2, p. 183-192, 2010.

MUNJI, CECILIA A; BELE, MEKOU Y; IDINOBA, MONICA E; SONWA, D. J. Floods and mangrove forests, friends or foes? Perceptions of relationships and risks in Cameroon coastal mangroves. Estuarine, Coastal and Shelf Science, v. 140, p. 67-75, 2014.

NASCIMENTO, A; N.; OLIVEIRA, R. J.; MENEZES, J. E. A reciclagem do lixo urbano como fonte de renda e a preservação dos recursos naturais e ambientais. Revista Gestão Industrial, v. 13, n. 1, p. 22-37, 2017.

NOVAIS, L W; NETO, A; NEGREIROS, A. B; FREIRE, P. Percepção ambiental de jovens sobre o ecossistema manguezal no município de Ilhéus. Revista Tamoios, v. 11, n. 1, p. 193-203, 2015.

OLIVEIRA, A. M. S. Subsídio à gestão da Reserva Extrativista Marinha de Soure-Marajó-Pará: uma análise dos problemas e conflitos socioambientais. 2012. 126p. Dissertação (Mestrado em Gestão dos Recursos Naturais e Desenvolvimento Local na Amazônia) - Universidade Federal do Pará, Belém, 2012.

OLIVEIRA, N. R.; SANTOS, C. R.; TURRA, A. Percepção ambiental como subsídio para gestão costeira da Baía do Araçá, Litoral Norte do Estado de São Paulo, Brasil. Desenvolvimento e Meio Ambiente, v. 44, n. 1, p. 140-163, 2018.

PAULA, E. M. S.; SILVA, E. V.; GORAYEB, A. Percepção ambiental e dinâmica geoecológica: premissas para o planejamento e gestão ambiental. Sociedade $\boldsymbol{\&}$ Natureza, v. 26, n. 3, p. 511-518, 2014.

PINHEIRO, L. C. F.; SOUZA, L. S. M.; PONTES, A. N.; SILVA, G. V.; LIMA, A. M. M. Educação Ambiental e Participação Social: Sustentabilidade na Reserva Extrativista Marinha de Soure, Ilha Do Marajó, Pará, Brasil. Educação Ambiental em Ação, v. 46, n. 3, 2014.

REPOlHO, S. M.; CAMPOS, D. N. S.; TAVARES-MARTINS, A. C. C.; ASSIS, D. M. S.; PONTES, A. N. Percepções ambientais e trilhas ecológicas: concepções de meio ambiente em escolas do município de Soure, Ilha de Marajó (PA). Revista Brasileira de Educação Ambiental, v. 13, n. 2, p. 66-84, 2018.

RIBAS, A.; SCHMID, A.; RONCONI, E. Topofilia, conforto ambiental e o ruído urbano como risco ambiental: a percepção de moradores dos Setores Especiais Estruturais da cidade de Curitiba. Desenvolvimento e Meio Ambiente, v. 21, p. 183-199, 2010.

ROCHA, T. T.; TAVARES-MARTINS, A. C. C.; LUCAS, F. A. Traditional populations in environmentally protected areas: an ethnobotanical study in the Soure Marine Extractive Reserve 
of Brazil. Boletín Latinoamericano y del Caribe de Plantas Medicinales y Aromáticas, v. 16, n. 4, p. 410-427, 2017.

ROCHA, T. T.; TAVARES-MARTINS, A. C. C.; LUCAS, F. A. Potencial terapêutico e composição química do óleo de bicho do tucumã (Astrocaryum vulgare Mart.) utilizado na medicina popular. Scientia Plena, v. 10, n. 11, p. 1-10, 2014.

RODRIGUES, C. Educação Ambiental e estudos do meio: o papel do educador. Revista Digital - Buenos Aires, v. 13. n. 13, p. 1-7, 2009.

ROY, A. K. D. Local community attitudes towards mangrove forest conservation: Lessons from Bangladesh. Marine Policy, v. 74, p. 186-194, 2016.

ROY, K. A. D. Ocean \& Coastal Management Determinants of participation of mangrove-dependent communities in mangrove conservation practices. Ocean and Coastal Management, v. 98, p. 70-78, 2014.

SANTUCCI, L.; CAROL, E.; TANJAL, C. Industrial waste as a source of surface and groundwater pollution for more than half a century in a sector of the Río de la Plata coastal plain (Argentina). Chemosphere, v. 206, p. 727-735, 2018.

SILVA, J. B.; SIMONIAN, L. T. População tradicional, Reservas Extrativistas e racionalidade estatal na Amazônia brasileira. Desenvolvimento e Meio Ambiente, v. 33, n. 1, p. 163-175, 2015.

SILVA, M. P.; PICHARILLO, C.; SILVA, G. C.; SILVA, F. L.; GONÇALVES-SILVA, J. C. Análise da influência dos aspectos sociais na percepção ambiental da população residente na microbacia do Córrego do Mineirinho, município de São Carlos-SP. Revista EIXO, v. 4, n. 2, p. 91-99, 2015.

SOE, K. T.; YEO-CHANG, Y. Perceptions of forest-dependent communities toward participation in forest conservation: A case study in Bago Yoma, South-Central Myanmar. Forest Policy and Economics, v. 100, p. 129-141, 2019.

TRENOUTH, A. L; HARTE, C.; DE HEER, C. P.; DEWAN, K.; GRAGE, A.; PRIMO, C.; CAMPBELL, M. L. Ocean \& Coastal Management Public perception of marine and coastal protected areas in Tasmania, Australia: Importance, management and hazards. Ocean and Coastal Management, v. 67, n. 1, p. 19-29, 2012.

ZAR, H. J. Biostatistical analysis. 5.ed. Pearson: New Jersey, 2009. 960 p.

ZHENG, L.; YANG, X.; LAI, S.; REN, H.; YUE, S.; ZHANG, Y.; HUANG, X.; GAO, Y.; SUN, Y.; WANG, Z.; FU, P. Impacts of springtime biomass burning in the northern Southeast Asia on marine organic aerosols over the Gulf of Tonkin, China. Environmental Pollution, v. 237, p. 285-297, 2018. 
Davison Márcio Silva de Assis

$\square$ davison-assis@hotmail.com

ORCiD: https://orcid.org/0000-0002-6693-5883
Submitted on: $30 / 07 / 2018$

Accepted on: 03/07/2020

2020;23:e01481

\title{
Ana Cláudia Caldeira Tavares-Martins
}

$\square$ tavaresmartins7@gmail.com

ORCiD: https://orcid.org/0000-0003-4972-036X

\author{
Norma Ely Santos Beltrão \\ $\square$ normaelybeltrao@gmail.com \\ ORCiD: https://orcid.org/0000-0003-1991-2977
}

\section{Priscila Sanjuan de Medeiros Sarmento \\ $\square$ priscilasanjuanbio@yahoo.com.br}

ORCiD: https://orcid.org/0000-0002-5001-9573

How to cite: ASSIS, D. M. S.; TAVARES-MARTINS, A. C. C.; BELTRÃO, N. E. S.; SARMENTO, P. S. M. Environmental perception in traditional communities: a study in Soure Marine Extractive Reserve, Pará, Brazil. Ambiente \& Sociedade. São Paulo, v. 23, p. 1-19, 2020. 


\title{
Percepção ambiental em comunidades tradicionais: um estudo na Reserva Extrativista Marinha de Soure, Pará, Brasil
}

\author{
Davison Márcio Silva de Assis \\ Ana Cláudia Caldeira Tavares-Martins \\ Norma Ely Santos Beltrão \\ Priscila Sanjuan de Medeiros Sarmento
}

São Paulo. Vol. 23, 2020

Artigo Original
Resumo: A Reserva Extrativista Marinha de Soure, localizada no Arquipélago do Marajó, foi criada para proteger sua biodiversidade e garantir a sustentabilidade dos seus ecossistemas, no entanto os problemas ambientais locais têm se tornado cada vez mais frequentes. Neste sentido, esse trabalho objetivou quantificar o nível de percepção ambiental, em quatro categorias de análise, nas comunidades pertencentes à esta Unidade de Conservação, a partir da elaboração de uma classificação de scores (de 1 a 10). Para tal, foram aplicados formulários estruturados na escala de Likert de 5 pontos. Os resultados foram quantificados e revelaram que os scores nas quatro categorias analisadas são elevados (acima de 9), indicando um alto nível de percepção. Além do mais, apresentou relação com a idade, escolaridade e número de pessoas no lar. Constatada a alta percepção, recomenda-se que as ações de sensibilização realizadas pelo órgão gestor da reserva sejam mantidas, a fim de preservar esses saberes.

Palavras-chave: Amazônia; Conhecimento Tradicional; Escala de Likert.

Como citar: ASSIS. D. M. S.; TAVARES-MARTINS, A. C. C.; BELTRÃO, N. E. S.; SARMENTO, P. S. M. Percepção Ambiental em comunidades tradicionais: um Estudo na Reserva Extrativista Marinha de Soure, Pará, Brasil. Ambiente \& Sociedade. São Paulo, v. 23, p. 1-20, 2020. 


\title{
Percepción ambiental en comunidades tradicionales: un estudio en la Reserva Extractiva Marina de Soure, Pará, Brasil
}

\author{
Davison Márcio Silva de Assis \\ Ana Cláudia Caldeira Tavares-Martins \\ Norma Ely Santos Beltrão \\ Priscila Sanjuan de Medeiros Sarmento
}

São Paulo. Vol. 23, 2020

Artículo original
Resumen: La Reserva Extractiva Marina Soure, ubicada en el Archipiélago de Marajó, fue creada para proteger su biodiversidad y garantizar la sostenibilidad de sus ecosistemas; sin embargo, los problemas ambientales locales se han vuelto cada vez más frecuentes. En este sentido este estudio tuvo como objetivo cuantificar el nivel de percepción ambiental, en cuatro categorías de análisis, de comunidades da esta unidad de conservación, con la elaboración de una clasificación de puntaje (del 1 al 10). Para esto, se aplicaron formularios en forma de una escala Likert de 5 puntos. Los resultados se cuantificaron y revelaron altas puntuaciones en las cuatro categorías analizadas (por encima de 9). Además, el nivel de percepción estuvo relacionado con la edad, la educación y el número de personas en el hogar. Una vez que se verifica la alta percepción, se recomienda mantener las acciones de sensibilización llevadas a cabo por el organismo gestor de la reserva, para preservar este conocimiento.

Palabras-clave: Amazonía; Conocimiento Tradicional; Escala de Likert.

Como citar: ASSIS. D. M. S.; TAVARES-MARTINS, A. C. C.; BELTRÃO, N. E. S.; SARMENTO, P. S. M. Percepción ambiental en comunidades tradicionales: un estudio en la Reserva Extractiva Marina de Soure, Pará, BrasilAmbiente \& Sociedade. São Paulo, v. 23, p. 1-20, 2020. 